\title{
Evaluation of Noncontract computed tomography in diagnosing acute appendicitis
}

\author{
Chavan $\mathbf{A}^{1}$, Jamdade $\mathbf{P T}^{2}$ \\ ${ }^{1}$ Dr Aashish R. Chavan, Assistant Professor, Department of Surgery, ${ }^{2}$ Dr P.T. Jamdade, Professor and Head, Department of \\ Surgery, Both authors are affiliated with Dr Shankarrao Chavan Government Medical College Nanded, Maharashtra, India.
}

Address for Correspondence: Dr Aashish R. Chavan, Eamil: aashish.chavan85@gmail.com

\begin{abstract}
Introduction: Appendicitis is a common disease, having a lifetime incidence of $7 \%$. Surgeons have traditionally accepted negative appendectomy rate up to $20 \%$. It is because of clinical myriad. Objectives of study were to determine the role of Noncontract Computed Tomography (NCCT) imaging in the detection of suspicious case of appendicitis. To estimate negative appendectomy rate (NAR) in preoperative evaluation of computed tomography (CT). Evaluate significance of Clinical, radiological and intraoperative parameters for diagnosing appendicitis. Material and Method: This is evaluation of diagnostic test of 450 patients coming to Emergency Department with suspicion of acute Appendicitis have undergone NCCT. The study will be carried out in the Department of surgery Dr Shankarrao Chavan Government Medical College Nanded over a period of 24 months. Result: An appendectomy was performed in 367 patients. All 367 patients underwent surgery their clinical and radiological correlation and intra-operative finding noted and surgical specimen sent for histopathological correlation. Clinically right iliac fossa pain, vomitting, temperature, RIF Tenderness, were found to be more consistent with acute appendicitis with significant $\mathrm{p}$ values. On establishing role of NCCT abdominal scan in diagnosing acute appendicitis significant parameters are Enlarged Appendix, Periappendicial fat stranding, Focal cecal apical thickening, Intra luminal Air these parameter are significant with $\mathrm{p}$ values. Omentum in right iliac fossa, Inflammed appendix, Periappendicular free fluid/pus is more consistent intra-operatively during appendectomy with significant $p$ values 0.028.0.045, 0.026 respectively. Negative appendectomy rate in our study is $3.81 \%$. Conclusion: There was a significant reduction in the Negative Appendectomy Rate in patients undergoing NCCT for diagnosis. Uses of specific clinical radiological and intra-operative parameters become significant in diagnosing appendicitis. NAR might have medico legal importance to debate for difficult in diagnosing appendicitis preoperatively.
\end{abstract}

Keyword: Negative appendectomy rate, Noncontract computed tomography, Appendicitis

\section{Introduction}

Appendicitis is a common disease, having a lifetime incidence of $7 \%$ [1]. In patients presenting to the emergency department, acute appendicitis is one of the most common causes of acute lower abdominal and right lower quadrant pain. Appendectomy is one of the most common surgical procedures.

However, the preoperative clinical diagnosis of acute appendicitis remains challenging even for experienced surgeons. In $20-30 \%$ of the cases myriad gastrointestinal, genitourinary, and gynaecologic conditions can have similar presentations $[2,3,4]$. Despite the high prevalence of appendicitis, the diagnosis is still problematic and

Manuscript Received: $20^{\text {th }}$ May 2017

Reviewed: $30^{\text {th }}$ May 2017

Author Corrected: $8^{\text {th }}$ June 2017

Accepted for Publication: $15^{\text {th }}$ June 2017 perforation can occur within 24 hours of the onset of symptoms [5]. To avoid additional morbidity from getting missed or diagnosis of acute appendicitis getting delayed, surgeons have traditionally accepted that up to $20 \%$ of patients undergoing appendectomy for suspected acute appendicitis will have a normal appendix. This has come to be accepted as negative appendectomy rate [2].

A significant number of patients without acute appendicitis who have equivocal clinical presentations could be spared the expense and morbidity of surgery by improved diagnosis withjudicious use of preoperative imaging. Conversely, patients with atypical presentations of acute appendicitis could be spared the morbidity and burden on health care resources associated with missed or 


\section{Original Research Article}

late diagnosis and consequent delay in appropriate treatment besides the risk of complications [5].

Non contrast Computerized Tomography (NCCT) is viable option available in the emergency diagnosis of acute appendicitis which is attractive for several reasons.

Administration of oral contrast consumes valuable time in today's fast-paced and overcrowded Emergency Department. The contrast may taste unpleasant, and may get aspirated in patients who are actively vomiting. Moreover the administration of oral contrast can also be a concern of delaying the scheduling of surgery. On the other hand, intravenous contrast carries the risk of contrast induced nephropathy and allergic reactions.

\section{Aim and Objectives}

To determine the role of Noncontract Computed Tomography (NCCT) imaging in the detection of suspicious case of appendicitis. To estimate negative appendectomy rate (NAR) in preoperative evaluation of computed tomography. Evaluate significance of Clinical, radiological and intra-operative parameters for diagnosing appendicitis.

\section{Material and Methods}

Study design: evaluation of diagnostic test.

Study setting: Department of surgery, Dr Shankarrao Chavan Government Medical College, Nanded.

Inclusion criteria: All Patients presenting in emergency department, outdoor/indoor department or referred from other department with right side abdominal pain with a clinical, radiological diagnosis of acute Appendicitis.

Exclusion criteria: Women who are pregnant or preparing for pregnancy, patients with appendicular lump, NCCT interpreted as showing normal findings \& Patients who failed to return for a follow-up visit.

Participants: Patients for this study was selected from the patients who undergone appendectomy for suspicious case of acute appendicitis at Department of surgery, Dr Shankarrao Chavan Government Medical College, Nanded.

\section{Variables}

Clinical finding- Right iliac fossa pain, vomiting, temperature, RIF Tenderness,

Radiological - Enlarged Appendix, Periappendicieal fat stranding, Focal cecal apical thickening, Intra luminal Air
Intra-operative- Omentum in right iliac fossa, inflamed appendix, Periappendicular free fluid / pus,

Data Source: Predesigned Proforma.

Time frame to address the study: From June 2014-May 2016

Sample size: The sample size was calculated by using $94 \%$ sensitivity and $95 \%$ specificity of NCCT for diagnosing appendicitis[14], the outcome of sample size calculation was 310 for sensitivity and 20 for specificity by using $7 \%$ prevalence of appendicitis[1], 10\% absolute precision and 95\% confidence level. The higher value i.e.310 was selected as sample size for study. The $10 \%$ non-response was added in the sample size so it became 343. But we had decided to enroll maximum number of patients in our study in two year duration of study. The 450 patients have undergone NCCT abdomen for the evaluation of acute abdomen in Emergency Department with suspicion of acute Appendicitis. After the follow up of two weeks, 367 patients have undergone appendectomy on the basis of clinical and radiological diagnosis and 83 patients were loss to follow up or NCCT is not suggestive of appendicitis.

\section{Methodology}

Before starting the study, an Ethical Clearance certificate was taken from the Ethical Committee of our Medical College. The informed consent was obtained from every patient after explaining the purpose of study.

Patients for this study was selected from the patients who undergone appendectomy, there Clinical parameters, NCCT findings and intraoperative finding are noted and evaluated its significance in diagnosing appendicitis. After removal, the surgical specimen was sent for histopathological examination and final diagnosis.

We determined the NAR by reviewing pathology records to determine whether removed appendices were acutely inflamed. All acutely inflamed appendices were categorized as positive, whereas all other findings were categorized as negative. Negative appendectomy rate (NAR) - defined as the portion of pathologically normal appendices removed surgically in patients suspected of having acute appendicitis

Statistical Methods- Descriptive statistical analysis was performed to calculate the means with corresponding standard deviations (S.D.). The chi-square $\left(\mathrm{X}^{2}\right)$ test was used to compare the difference between proportions. The $\mathrm{p}$ value $<0.05$ was taken to be statistically significant. The sensitivity, specificity and predictive value of the NCCT were calculated. 


\section{Results}

All 367 (81.4\%) patients who underwent surgery after surgical consent suspecting acute appendicitis on the basis of clinical and radiological correlation and intraoperative finding noted and surgical specimen sent for histopathological correlation. Our study population consisted of 243 men (66\%) and 124 women (34\%) (Table 2), who ranged in age from 11 to 50 years; the average age was 28 years (Table 1$)$.

Table-1: Percentage of demographic profile

\begin{tabular}{|c|c|c|c|c|c|}
\hline Age Groups & $\begin{array}{c}\text { Number of } \\
\text { Patients } \\
\end{array}$ & $\%$ & Sex & $\begin{array}{c}\text { Number of } \\
\text { Patients } \\
\end{array}$ & $\%$ \\
\hline $11-20$ & 88 & $24 \%$ & Male & 243 & $66 \%$ \\
\hline $21-30$ & 117 & $32 \%$ & Female & 124 & $34 \%$ \\
\hline $31-40$ & 110 & $30 \%$ & Total & 367 & $100 \%$ \\
\hline $41-50$ & 52 & $14 \%$ & & & \\
\hline Total & 367 & $100 \%$ & & & \\
\hline Mean \pm SD & $28.60 \pm 9.17$ & & & & \\
\hline
\end{tabular}

Clinically right iliac fossa pain, vomiting, temperature, RIF Tenderness (table 2), were found to be more consistent with acute appendicitis with significant p values $0.007,0.017,0.038,0.045$ respectively. Similarly Total leukocyte count (table 4) was significant ( $\mathrm{p}$ value 0.046 ) criteria in diagnosing appendicitis.

Table-2: Relation of RIF pain, vomiting, temperature, RIF Tenderness with Acute Appendicitis

\begin{tabular}{|c|c|c|c|c|c|c|c|c|c|}
\hline & \multicolumn{2}{|c|}{ Histopathology Result } & \multirow{2}{*}{$\begin{array}{c}\mathrm{X} 2 / \mathrm{P} \\
\text { value }\end{array}$} & \multirow[t]{2}{*}{ Sensitivity } & \multirow{2}{*}{$\begin{array}{c}\text { Specifici } \\
\text { ty }\end{array}$} & \multirow[t]{2}{*}{ PPV } & \multirow[t]{2}{*}{ NPV } & \multirow{2}{*}{$\begin{array}{c}\text { Accurac } \\
\mathbf{y}\end{array}$} \\
\hline & & $\begin{array}{c}\text { Positive } \\
\text { cases }\end{array}$ & $\begin{array}{c}\text { Negative } \\
\text { Cases }\end{array}$ & & & & & & \\
\hline \multirow{3}{*}{$\begin{array}{c}\text { Right } \\
\text { Iliac } \\
\text { fossa pain }\end{array}$} & Yes & $\begin{array}{c}308 \\
(91.3 \%)\end{array}$ & $\begin{array}{c}7 \\
(25 \%)\end{array}$ & \multirow[t]{3}{*}{$\begin{array}{l}98.546 \\
1 / 0.007\end{array}$} & \multirow[t]{3}{*}{$91.3 \%$} & \multirow[t]{3}{*}{$75.0 \%$} & \multirow[t]{3}{*}{$97.7 \%$} & \multirow[t]{3}{*}{$42.9 \%$} & \multirow[t]{3}{*}{$90.0 \%$} \\
\hline & No & $\begin{array}{c}30 \\
(8.7 \%)\end{array}$ & $\begin{array}{c}22 \\
(75 \%)\end{array}$ & & & & & & \\
\hline & Total & $\begin{array}{c}338 \\
(100 \%)\end{array}$ & $\begin{array}{c}29 \\
(100 \%)\end{array}$ & & & & & & \\
\hline \multirow[t]{3}{*}{ Vomiting } & Yes & $\begin{array}{c}228 \\
(67.4 \%)\end{array}$ & $\begin{array}{c}0 \\
(0 \%)\end{array}$ & & \multirow[t]{3}{*}{$67.4 \%$} & \multirow[t]{3}{*}{$100.0 \%$} & \multirow[t]{3}{*}{$100.0 \%$} & \multirow[t]{3}{*}{$21.1 \%$} & \multirow[t]{3}{*}{$70.0 \%$} \\
\hline & No & $\begin{array}{c}110 \\
(32.6 \%)\end{array}$ & $\begin{array}{c}29 \\
(100 \%)\end{array}$ & & & & & & \\
\hline & Total & $\begin{array}{c}338 \\
(100 \%)\end{array}$ & $\begin{array}{c}29 \\
(100 \%)\end{array}$ & & & & & & \\
\hline \multirow[t]{3}{*}{ Temperature } & Yes & $\begin{array}{c}271 \\
(80.4 \%)\end{array}$ & $\begin{array}{c}8 \\
(25 \%)\end{array}$ & \multirow[t]{3}{*}{$\begin{array}{c}43.66 / \\
0.038\end{array}$} & \multirow[t]{3}{*}{$80.4 \%$} & \multirow[t]{3}{*}{$75.0 \%$} & \multirow[t]{3}{*}{$97.4 \%$} & \multirow[t]{3}{*}{$25.0 \%$} & \multirow[t]{3}{*}{$80.0 \%$} \\
\hline & No & $\begin{array}{c}66 \\
(19.6 \%)\end{array}$ & $\begin{array}{c}22 \\
(75 \%)\end{array}$ & & & & & & \\
\hline & Total & $\begin{array}{c}337 \\
(100 \%)\end{array}$ & $\begin{array}{c}30 \\
(100 \%)\end{array}$ & & & & & & \\
\hline \multirow[t]{3}{*}{ RIF Tenderness } & Yes & $\begin{array}{c}315 \\
(93.5 \%)\end{array}$ & $\begin{array}{c}14 \\
(48.27)\end{array}$ & \multirow[t]{3}{*}{$\begin{array}{c}58.059 / 0 \\
.045\end{array}$} & \multirow[t]{3}{*}{$93.5 \%$} & \multirow[t]{3}{*}{$50.0 \%$} & \multirow[t]{3}{*}{$95.6 \%$} & \multirow[t]{3}{*}{$40.0 \%$} & \multirow[t]{3}{*}{$90.0 \%$} \\
\hline & No & $\begin{array}{c}23 \\
(6.5 \%)\end{array}$ & $\begin{array}{c}15 \\
(51.72 \%)\end{array}$ & & & & & & \\
\hline & Total & $\begin{array}{c}338 \\
(100 \%)\end{array}$ & $\begin{array}{c}29 \\
(100 \%)\end{array}$ & & & & & & \\
\hline
\end{tabular}

Table-3: Relation of haematological parameters with Acute Appendicitis

\begin{tabular}{|c|c|c|c|c|c|}
\hline \multirow{2}{*}{} & \multicolumn{2}{|c|}{ Positive cases } & \multicolumn{2}{c|}{ Negative Cases } & \multirow{2}{*}{$\mathrm{p}$ value } \\
\cline { 2 - 5 } & Mean \pm SD & Min-Max & Mean \pm SD & Min-Max & 0.046 \\
\hline TLC & $9448 \pm 2843$ & $4568-18354$ & $12600 \pm 4173$ & $7730-17900$ & 0 \\
\hline
\end{tabular}


Original Research Article

On establishing role of NCCT abdominal scan in diagnosing acute appendicitis parameters considered are (table 4) Enlarged appendix, Appendiceal thickening, Periappendiceal fat stranding, Focal cecal apical thickening, Appendicolith, Intraluminal air, Extraluminal air it is found that (table 4) these are significant in diagnosing acute appendicitis with $p$ values $0.045,0.016,0.0320 .029$ respectively(table 4$)$.

Table-4: Relation of NCCT abdomen parameters with Acute Appendicitis

\begin{tabular}{|c|c|c|c|c|c|c|c|c|c|}
\hline \multirow{5}{*}{$\begin{array}{l}\text { Enlarged } \\
\text { Appendix }\end{array}$} & & \multirow[t]{2}{*}{ Total } & \multicolumn{4}{|c|}{ Histopathology Result } & \multirow{5}{*}{$\begin{array}{c}\mathrm{X}^{2} / \mathrm{P} \text { value } \\
60.2331 / 0.04 \\
5\end{array}$} & \multirow{2}{*}{$\begin{array}{l}\text { Sensitivity } \\
\text { Specificity }\end{array}$} & \multirow{2}{*}{$\begin{array}{l}93.5 \% \\
50.0 \%\end{array}$} \\
\hline & & & $\begin{array}{c}\text { Positive } \\
\text { cases }\end{array}$ & $\%$ & $\begin{array}{c}\text { Negative } \\
\text { Cases }\end{array}$ & $\%$ & & & \\
\hline & Yes & 330 & 316 & $93.5 \%$ & 14 & $48.27 \%$ & & PPV & $95.6 \%$ \\
\hline & No & 37 & 22 & $6.5 \%$ & 15 & $51.72 \%$ & & NPV & $40.0 \%$ \\
\hline & Total & 367 & 338 & $100 \%$ & 29 & $100 \%$ & & Accuracy & $90.0 \%$ \\
\hline \multirow{5}{*}{$\begin{array}{l}\text { Periappen- } \\
\text { dicieal fat } \\
\text { stranding }\end{array}$} & & Total & & istopath & ogy Result & & \multirow{5}{*}{$\begin{array}{l}\mathrm{X}^{2} / \mathrm{P} \text { value } \\
71.51 / 0.016\end{array}$} & Sensitivity & $87.0 \%$ \\
\hline & & & $\begin{array}{c}\text { Positive } \\
\text { cases }\end{array}$ & $\%$ & $\begin{array}{c}\text { Negative } \\
\text { Cases }\end{array}$ & $\%$ & & Specificity & $75.0 \%$ \\
\hline & Yes & 301 & 294 & $87.0 \%$ & 7 & $\begin{array}{c}24.13 \\
\%\end{array}$ & & PPV & $97.6 \%$ \\
\hline & No & 66 & 44 & $13.0 \%$ & 22 & $\begin{array}{c}75.86 \\
\%\end{array}$ & & NPV & $33.3 \%$ \\
\hline & Total & 367 & 338 & $100 \%$ & 29 & $100 \%$ & & Accuracy & $86.0 \%$ \\
\hline \multirow{5}{*}{$\begin{array}{c}\text { Focal cecal } \\
\text { apical } \\
\text { thickening }\end{array}$} & & Total & \multicolumn{4}{|c|}{ Histopathology Result } & & Senstivity & $60.9 \%$ \\
\hline & & & $\begin{array}{c}\text { Positive } \\
\text { cases }\end{array}$ & $\%$ & $\begin{array}{c}\text { Negative } \\
\text { Cases }\end{array}$ & $\%$ & & Specificity & $\begin{array}{c}100.0 \\
\%\end{array}$ \\
\hline & Yes & 206 & 206 & $60.9 \%$ & 0 & $0 \%$ & & PPV & $\begin{array}{c}100.0 \\
\%\end{array}$ \\
\hline & No & 161 & 132 & $39.1 \%$ & $4-29$ & $100 \%$ & & NPV & $18.2 \%$ \\
\hline & Total & 367 & 338 & $100 \%$ & $4-29$ & $100 \%$ & & Accuracy & $64.0 \%$ \\
\hline \multirow{5}{*}{$\begin{array}{c}\text { Intraluminal } \\
\text { Air }\end{array}$} & & Total & \multicolumn{4}{|c|}{ Histopathology Result } & \multirow{5}{*}{$\begin{array}{l}\mathrm{X}^{2} / \mathrm{P} \text { value } \\
52.97 / 0.029\end{array}$} & Senstivity & $82.6 \%$ \\
\hline & & & $\begin{array}{c}\text { Positive } \\
\text { cases }\end{array}$ & $\%$ & $\begin{array}{c}\text { Negative } \\
\text { Cases }\end{array}$ & $\%$ & & Specificity & $75.0 \%$ \\
\hline & Yes & 286 & 279 & $82.6 \%$ & 7 & $24.13 \%$ & & PPV & $97.4 \%$ \\
\hline & No & 81 & 59 & $17.4 \%$ & 22 & $75.86 \%$ & & NPV & $27.3 \%$ \\
\hline & Total & 367 & 338 & $100 \%$ & 29 & $100 \%$ & & Accuracy & $82.0 \%$ \\
\hline
\end{tabular}

Omentum in right iliac fossa, Inflamed appendix, Periappendicular free fluid / pus are more consistent intra-operatively during appendectomy with significant $\mathrm{p}$ values $0.028 .0 .045,0.026$ respectively (Table 5)

Table- 5: Relation of Intra-operative finding with Acute Appendicitis.

\begin{tabular}{|c|c|c|c|c|c|c|c|c|c|}
\hline & \multicolumn{2}{|c|}{ Histopathology Result } & \multirow{2}{*}{$\begin{array}{c}\mathbf{P} \\
\text { value }\end{array}$} & \multirow[t]{2}{*}{ Sensitivity } & \multirow[t]{2}{*}{ Specificity } & \multirow[t]{2}{*}{ PPV } & \multirow[t]{2}{*}{ NPV } & \multirow[t]{2}{*}{ Accuracy } \\
\hline & & $\begin{array}{c}\text { Positive } \\
\text { cases }\end{array}$ & $\begin{array}{l}\text { Negative } \\
\text { Cases }\end{array}$ & & & & & & \\
\hline \multirow[t]{2}{*}{$\begin{array}{c}\text { Omentum in } \\
\text { RIF }\end{array}$} & Yes & $\begin{array}{c}323 \\
(95.7 \%)\end{array}$ & $15(50 \%)$ & \multirow[t]{2}{*}{0.028} & \multirow[t]{2}{*}{$95.7 \%$} & \multirow[t]{2}{*}{$50 \%$} & \multirow[t]{2}{*}{$95.6 \%$} & \multirow[t]{2}{*}{$50 \%$} & \multirow[t]{2}{*}{$92 \%$} \\
\hline & No & $5(4.3 \%)$ & $15(50 \%)$ & & & & & & \\
\hline \multirow[t]{2}{*}{$\begin{array}{l}\text { Inflamed } \\
\text { Appendix }\end{array}$} & Yes & $\begin{array}{c}316 \\
(93.5 \%)\end{array}$ & $\begin{array}{c}14 \\
(48.27 \%)\end{array}$ & \multirow[t]{2}{*}{0.045} & \multirow[t]{2}{*}{$93.5 \%$} & \multirow[t]{2}{*}{$50 \%$} & \multirow[t]{2}{*}{$95.5 \%$} & \multirow[t]{2}{*}{$40 \%$} & \multirow[t]{2}{*}{$90 \%$} \\
\hline & No & $22(6.5 \%)$ & $15(51.72 \%)$ & & & & & & \\
\hline \multirow{2}{*}{$\begin{array}{l}\text { Periappendicul } \\
\text { ar Free Fluid }\end{array}$} & Yes & $213(63 \%)$ & $0(0 \%)$ & \multirow[t]{2}{*}{0.026} & \multirow[t]{2}{*}{$63.0 \%$} & \multirow[t]{2}{*}{$100 \%$} & \multirow[t]{2}{*}{$100.0 \%$} & \multirow[t]{2}{*}{$19 \%$} & \multirow[t]{2}{*}{$66 \%$} \\
\hline & No & $125(37 \%)$ & $29(100 \%)$ & & & & & & \\
\hline
\end{tabular}

HPE reports of 14 appendectomy specimen showed normal appendix. Negative appendectomy rate in our study is $3.81 \%$. 


\section{Discussion}

Six studies in this systematic review included radiologists as investigators and all support the use of noncontrast CT scans for the diagnosis of appendicitis [6-11]. Ashraf et al [7] state that a "certain level of experience is required for skilful interpretation" of noncontrast CT and have established an imaging protocol at their institution that includes noncontrast $\mathrm{CT}$ for evaluating the appendix.

Lane et al [12] mention that as a result of their study on noncontrast CT for suspected appendicitis; their institution now considers noncontrast $\mathrm{CT}$ as an alternative to ultrasonography for diagnosing appendicitis. Therefore, it appears that there is already some degree of acceptance for using noncontrast CT scans among radiologists for the diagnosis of appendicitis.

Two recently published meta-analyses comparing CT and ultrasonography in the diagnosis of appendicitis reported similar results to ours, with respect to the ability of CT to rule out appendicitis. The negative likelihood ratio of 0.08 according to our SROC analysis was consistent with that reported by van Randenet al [13]. Terasawa et al [14] reported summary estimates of $94 \%$ (95\% CI 91 to $95 \%$ ) for sensitivity, 95\% (95\% CI 93 to $96 \%$ ) for specificity, and 0.09 for the negative likelihood ratio.

Terasawa et al [14] observed that the test characteristics among the individual studies were similar despite variation in the use of contrast and CT technology but methodological limitations may have inflated estimates of diagnostic accuracy. Our systematic review is unique in that it specifically focuses on the diagnostic accuracy of noncontrast CT in adult patients suspected of having acute appendicitis.

Reviews by Terasawa et al [14], Weston et al [15], and van Randen et al [16] compare the use of CT to ultrasonography in diagnosis of acute appendicitis but include only 2 to 3 studies that assess the accuracy of noncontrast $\mathrm{CT}$ and also include paediatric populations.

As with any diagnostic test that does not have perfect sensitivity or specificity, CT cannot exclude appendicitis with $100 \%$ certainty and must be interpreted within the clinical context. Depending on the individual patient's condition and circumstances, clinical judgment must be used when deciding to perform contrast-enhanced or unenhanced CT for suspected appendicitis. The ultimate goal of CT imaging in patients presenting with abdominal pain suspicious for appendicitis is to make a prompt diagnosis and decrease the rate of appendectomies performed on patients without appendicitis. Although some authors have reported a decrease in the rate of appendectomies performed on patients without appendicitis with the use of helical CT [17], others argue that there has been little change in the rate of surgical intervention or rate of perforation [18].

There was a significant reduction in the NAR in a patients undergoing NCCT for diagnosis. Use of specific clinical radiological and intraoperative parameters becomes significant in diagnosing appendicitis. NAR might have medico legal importance to debate for difficulty in diagnosing appendicitis preoperatively.

\section{Conclusions}

We found the diagnostic accuracy of noncontrast CT for the diagnosis of acute appendicitis in the adult population to be adequate for clinical decision making in the ED setting.

Potential advantages of noncontrast scanning in today's overcrowded ED include rapid diagnosis, early disposition, cost savings, and higher patient satisfaction, as well as the elimination of contrast-related adverse affects.

Recommendations- On the basis of the finding of this study the following recommendations may be considered for inclusion in the protocol for management of acute appendicitis.

1. In suspected case of acute appendicitis NCCT abdomen should be done as the patient presents in the emergency room.

2. If NCCT abdomen findings do not categorically support the clinical suspicion of acute appendicitis then the patient should be managed conservatively and followed up diligently.

3. CECT abdomen should be considered as a next line of investigation if the earlier clinical or radiological findings are at variance in a patient with myriad presentations.

4. A comprehensive Scoring system for diagnosing acute appendicitis should be develop based model of study extended to involve a larger cohort.

5. The reliance on ultrasound scanning as an investigative tool for diagnosing acute appendicitis should be placed only in conjuction with NCCT findings.

Conflict of interest: None declared. Funding: Nil, Permission from IRB: Yes 


\section{References}

1. Berry J Jr, Malt RA. Appendicitis near its centenary. Ann Surg 1984;200:567 -575 Lewis FR, Holcroft JW, Boey J, et al. Appendicitis: critical review of 1000 patients. Arch Surg 1975;110:677 -684.

2. Bongard F, Landers DV, Lewis F. Differential diagnosis of appendicitis and pelvic inflammatory disease. Am J Surg 1985;150:90 -96

3. Eldar S, Nash E, Sabo E, Matter I, Kunin J, Mogilner JG, Abrahamson J. Delay of surgery in acute appendicitis. Am J Surg. 1997 Mar;173(3):194-8.

4. Pinto Leite N, Pereira JM, Cunha R, Pinto P, Sirlin C. CT evaluation of appendicitis and its complications: imaging techniques and key diagnostic findings. AJR Am J Roentgenol. 2005 Aug;185(2):406-17.

5. Weston AR, Jackson TJ, Blamey S. Diagnosis of appendicitis in adults by ultrasonography or computed tomography: a systematic review and meta-analysis. Int J Technol Assess Health Care. 2005 Summer;21(3): 368-79.

6. Ashraf K, Ashraf O, Bari V, et al. Role of focused appendiceal computed tomography in clinically equivocal acute appendicitis.J Pak Med Assoc. 2006;56:200203.

7. Ege G, Akman H, Sahin A, et al. Diagnostic value of unenhanced helical CT in adult patients with suspected acute appendicitis. $\mathrm{Br} \mathrm{J}$ Radiol. 2002; 75: 721725 .

8. in't Hof KH, van Lankeren W, Krestin GP, et al. Surgical validation of unenhanced helical computed tomography in acute appendicitis. Br J Surg. 2004; 91: 1641-1645.

9. Keyzer C, Zalcman M, De Maertelaer V, Coppens E, Bali MA, Gevenois PA, Van Gansbeke D. Comparison of US and unenhanced multi-detector row CT in patients suspected of having acute appendicitis. Radiology. 2005 Aug;236(2):527-34.
10. Stacher R, Portugaller H, Preidler KW, et al. Acute appendicitis in unenhanced spiral CT: diagnostic luxury or benefit [in German]? Rofo. 1999;171:26-31.

11.T amburrini S, Brunetti A, Brown M, et al. Acute appendicitis: diagnostic value of nonenhanced CT with selective use of contrast in routine clinical settings. Eur Radiol.2007;17:2055-2061.

12. Lane MJ, Katz DS, Ross BA, et al. Unenhanced helical CT for suspected acute appendicitis. AJR Am J Roentgenol. 1997;168: 405-409.

13. van Randen A, Bipat S, Zwinderman AH, Ubbink DT, Stoker J, Boermeester MA. Acute appendicitis: metaanalysis of diagnostic performance of CT and graded compression US related to prevalence of disease. Radiology. 2008 Oct;249(1):97-106. doi: 10.1148/radiol. 2483071652. Epub 2008 Aug 5.

14. Terasawa T, Blackmore C, Bent S, et al. Systematic review: computed tomography and ultrasonography to detect acute appendicitis in adults and adolescents. Ann Intern Med. 2004; 141:537-546.

15. Weston AR, Jackson TJ, Blamey S. Diagnosis of appendicitis in adults by ultrasonography or computed tomography: a systematic review and meta-analysis. Int J Technol Assessm Health Care. 2005;21:368-379.

16. van Randen A, Bipat S, Zwinderman AH, Ubbink DT, Stoker J, Boermeester MA. Acute appendicitis: metaanalysis of diagnostic performance of CT and graded compression US related to prevalence of disease. Radiology. 2008 Oct;249(1):97-106. doi: 10.1148/radiol. 2483071652. Epub 2008 Aug 5.

17. Peck J, Peck A, Peck C, et al. The clinical role of noncontrast helical computed tomography in the diagnosis of acute appendicitis. Am J Surg. 2000;180:133-136.

18. Togawa A, Kimura F, Chiku T, et al. Simple way to improve accuracy in diagnosis of quadrant inflammatory disease: how to avoid adverse laparotomy by using plain CT. Hepatogastroenterology. 2005;52: 135-138.

\section{How to cite this article?}

Chavan A, Jamdade PT. Evaluation of Noncontract computed tomography in diagnosing acute appendicitis.Int $J$ surg Orthopedics.2017;3(2):38-43.doi:10.17511/ijoso.2017.i02.03. 